\title{
Remedial Instructions for C-level ESL College Students with Severe Listening Disabilities
}

\author{
Xiuli Zhang \\ School of Foreign Languages, Shanghai University, Shanghai, China
}

\begin{abstract}
This paper suggested two strategies to improve the listening capacity for C-level ESL College Students with Severe Listening Disabilities: boosting self-confidence and providing pre-listening vocabulary support. Special instructions shall be adopted for C-level ESL College Students, for they encounter severe listening problems that are vital for their second language acquisition.
\end{abstract}

Index Terms - remedial instruction, ESL, listening disabilities, College English, C-level students

\section{THE PROBLEM}

In China, College English in universities and colleges face common problems. As one of the compulsory courses, College English is required to be finished in two years. The first year college students have to take a special examination to be categorized as different levels of English learners, namely A level, B level, C level. In this test, especially in Shanghai University, listening counts for much. Consequently, students from economically developed regions such as Shanghai, Zhejiang Province, Jiangsu province would perform better than those from the west, the less developed regions and provinces, such as Tibet. In addition, some provinces such as Guizhou would have a different way of having the listening test. For example, the examiners would play the listening tape for the test twice, even more. Therefore when these students come to listening tests in which the tape is allowed to be played only once, they would meet with difficulties of understanding and comprehension. These students are the C-level students with severe listening disabilities.

The problem is that there is no fundamental difference concerning the teaching methods between the C-level students with the A and B. Usually different leveled students would have different text books for the same course College English according to the level of difficulties. But the teaching method is similar. There is no special adjustment to students' listening disabilities. Currently, the series Twenty-first Century College English is the text book for C-level students. In this series, the text book Watching, Listening \& Speaking is designed to improve the listening ability of this level. In this book, communication skill is laid the greatest importance. It aims to prepare students for the future career. Thus, most listening and speaking materials are about business English. For example, the first unit in Book 2 focuses on how to make complain in the workplace, and unite 2 is about how to listen in the workplace, etc. For the majority of the freshmen, these materials are far from their campus life and daily concern. In addition, the dictions and expressions form a sharp contrast with their high school English. It is found that $90 \%$ of the freshmen have problem with the listening and speaking class. Both the vocabulary and context are unfamiliar to the students. The teachers find it difficult to move the class forward, for students simply have not much interest in it, and they cannot follow the whole class.

Based on the current situation, this paper has two suggestions. The first one is to boost students' confidence of learning English with some strategies. The second is to enhance students' basic listening skills from the very fundamental level. These two approaches are well connected with each other. If the students have the confidence in listening, they would like to follow the teachers and continue their studies. Otherwise they would probably give up learning English totally, just as some C-level students have done. And if the students grasp the basic listening skills step by step, their confidence would be gradually boosted. Then they would come into a positive cycle of learning English. The problem is not to learn how much, but how to learn.

\section{THE IMPORT ANCE OF LISTENING}

Listening plays a vital role in language acquisition for it helps students develop other language skills (Feyten, 1991; Mendelsohn, 1995; Rost, 2002). According to Nunan, listening is the fundamental skill in language learning. Without effective listening skills, learners will find it difficult to communicate effectively. And he also believes that more than half of the time that students spend on functioning in a foreign language will be devoted to listening (1998).

Two dominating views, "Bottom-up" processing view and the "Top-down" interpretation view, concerning the pedagogy of listening over the last twenty years shed new insights. In the bottom-up processing model, as is believed, listening is a process of decoding the sounds that one hears in a linear fashion, from the smallest meaningful units (or phonemes) to complete texts. That is to say, phonemic units are decoded and linked together to form words, words are linked together to form phrases, phrases are linked together to form utterances, and utterances are linked together to 
form complete meaningful texts. While for the top-down view, it is the listener who actively constructs, or reconstructs the original meaning of the speaker using incoming sounds as clues. In this reconstruction process, prior knowledge of the context and situation within which the listening takes place is used by the listener to make sense of what he or she hears (Nunan, 1998). In this latter view, the prominence of background knowledge the listeners have possessed is emphasized. When they perceive and process the information they are hearing, the listeners use the prior knowledge to facilitate their attempt to grasp the incoming information by relating the familiar with the new one. If the listeners lack the prior knowledge, their efforts of comprehending the listening would be hampered. Therefore, whether the learners can effectively perform this processing determines the outcomes of their listening.

For the C-level students with severe listening disabilities, the Top-down view would be more effective in improving listening capacities. This is largely because, the C-level students is lack of associating between what they have learnt and what they are going to learn. On the one hand, they had always performed not well in doing listening tasks, that they have no confidence in doing them well. They tend not to associate with what they have known, for they believe that they have known nothing useful. This psychological problem has to be solved in order to improve students' listening abilities. On the other hand, teachers have not done enough to help students to consciously make the association happen. Pre-listening activities are even ignored. With liminal background information, C-level students find it more difficult to comprehend the listening, and their confidence in listening is weakened therefore.

\section{REMEDIAL INSTRUCTION}

Known as developmental education, basic skills education, compensatory education, preparatory education, and academic upgrading, remedial instruction is designed to assist students in order to achieve expected competencies. According to King (1973), remedial instruction can be regarded as those instructions that intend to correct bad habits, to bring students up to the level they are supposed to have reached in order to carry out requisite tasks of understanding the spoken and written word, of speaking and of writing. Remedial instruction is adopted more to teach children with learning disabilities (Torgesen et al., 2001). For the application of remedial instruction in adult, researches have done in United States (Bossone, 1966). They believed that not only children but also adult need remedial instruction. In Bossone's study, approximately 70 percent of the entering freshmen (of which there are approximately 270,000) in California public junior colleges fail the qualifying examination for English 1A; and, with the trend toward education for all persons through the age of twenty, there will be undoubtedly an increase in the number of students in need of remedial English work.

There is an assumption that the remedial English provided for native speakers of English will also do for students of English as a second language. However, there are differences between improving the English of the native speaker and improving the English of a foreign speaker (King, 1973). Researchers from countries and regions that English as nonnative language have done some researches in this field. Ho (2016) has examined the extent to which using an English Remedial Instruction Course enhances the vocabulary of Form 3 Malaysian students at a rural school in Sarawak, Malaysia. The study showed there were significant differences using Remedial Instruction enhance the learners' vocabulary.

In China, things are different. Here remedial instruction is also known as "buxiban" (simplified Chinese: 补习班) to help students to remain competitive with their peers of the same age. Students that go for remedial instruction are not altogether those having problem with learning. In addition, remedial instruction is popular in primary school, middle and high school years, rather than in the college, for the purpose of remedial instruction is to help students to get a highenough college entrance exam score to attend prestigious universities. After students were enrolled into universities, remedial instruction is seldom to be adopted. It is commonly accepted that college students shall be able to study by themselves. In addition, getting high scores in colleges are not that important as in high school. Therefore, remedial instruction is not popular in universities and colleges.

Whether college students in China need remedial instruction requires more discussions and researches. In Qiong's study (2012), the method of e-learning was adopted to demonstrate the effectiveness of remedial instruction in College English. It suggested methods such as individualized teaching, love-oriented teaching, motivation strategies and instruction with the help of technology, to facilitate students' listening comprehension. While Qiong's study has provided some important evidence for the positive effect of the remedial instruction in College English teaching, more studies are clearly needed to confirm this positive effect, considering especially the following problems in Qiong's study. This study intended to solve the problems of students of low-achievement through e-learning, such as making the PPT more attractive to students. It is effective to some extent. But some fundamental issue has not been covered. This paper is going to approach this problem from two perspectives, the one is physiological and the other is concerned with the most basic skills. In addition, as the fundamental capacity, listening is regarded as an important approach to English capacity improvement.

\section{Strategy: Boosting SelF-CONFIDENCE In ENGLish Listening}

Researches on improving listening comprehension for English as second language tend to lay great emphasis on skills rather than other factors such as emotion or phycology. Habte-Gabr's study (2006) has clearly shown that socio 
affective strategies play a major role in teaching mainstream subjects. It argued that socio-affective strategies were those that involve stimulating learning through establishing a level of empathy between the instructor and student. In Oxford's study (1990), the socio affective strategies include factors such as emotions and attitudes. It is believed that confidence in doing listening tasks is essential. It will help reduce the listeners' anxiety and promote their motivation in improving listening comprehension. According to Vandergrift, L. (2003), if the only purpose of using listening activities is to test students' comprehension ability, students would feel anxiety and under great presser, which would obstruct students' listening comprehension and confidence. Teachers shall use some strategies to guide students through the process of listening. They shall not only instruct them to successfully complete a listening task, but also guide them to have a clear picture of the whole process of listening, and motivate them to control their listening. In their influential book Learning Strategies in Second Language Acquisition (2001), O`Malley \& Chamot offer an account of the nature and significance of learning strategies, and demonstrate how to plan more effective instructional practices using the strategies. They believe that affective strategies influenced the learning situation immediately.

Many teachers disregard the importance of students" confidence in learning English. They put more value on students' motivation. However, students with high motivation do not necessary perform well in both classroom study and final examination. As one of the compulsory courses, college English takes 24 GPA points among. And usually if students fail C-1, they would probably fail C-2, C-3, for C-1 is the most basic and easiest. Most universities and colleges take the academic performance as the requirement for the entrance to the majors. If their GPA is not high enough, they would be excluded from the most popular majors. In a word, students have the motivation to learn English well. However, in each semester, there would be $10 \%$ of the C-level students fail the course. Most importantly, there are a large number of students who is not allowed to have the graduation certificate because of their failure in this course. They are allowed to re-attend the class after graduation, but most times they would fail again. This is partly because they have no enough time to study during the workday compared with that when they were in the college. Although some universities and colleges have abolished the regulation that students must pass the national English test: College English Band 4 before their graduation, and there are many criticism against the test itself, there is still much applause of college English in the labor market. Students are well conscious of the importance of college English and they certainly have the motivation. The bad academic performance is not due to the lack of motivation, but something else.

From the conversations with C-level students and observation of their behaviors in the classroom, this paper believes that lack of confidence in learning English count for much. C-level students do not necessary mean that they perform not satisfactorily in all the subjects, such as math and physics. On the contrary, they are very intelligent in fields other than English. In fact, in order to be enrolled by the universities, C-level students must have higher scores in other subjects, for their English is not very good. They have problem in English learning, not learning itself. They are confident in all subjects except English. And being categorized as C level, some students feel not very good. They determined to go to B level, which indicates that their confidence has been harmed to some extent.

In order to boost students' confidence of listening, teachers shall monitor all the process of listening tasks. Most importantly, teachers shall help students set goals. It is definitely important to set goals in English learning. However, C-level students are not able to set appropriate goals that can really motivate them and eventually help improve their confidence in learning. Most students have a very vague purpose, such as passing the final examination, or improving their English. But they have no specific measures of achieving these goals. Eventually they would totally forget what they have determined to accomplish in this semester during the learning process, and when the final examination day is approaching, they would feel intensely the anxiety and frustration. After several painful experiences, students would gradually suggest to themselves that they do not have the ability to improve English, and eventually give up totally. In this situation, teachers shall help them to set executable goals and plans step by step. Most college English teachers regard students as adult who shall be responsible for their study. They believe that as a college student, one shall be able to learn by oneself. However, for the C-level students, teachers shall help students build confidence step by step by monitoring the whole listening process. They shall tell the students the purpose of each listening activity, and allow them to have a clear idea of the results of listening by demonstrating the evaluation process.

Among the pre-listening activities, while-listening activities and post-listening activities, pre-reading activities shall be the focus for C-level students' teachers. Currently, in the College English classroom, while-listening activities and post-listening activities have been conducted well, while the pre-listening activities are mostly ignored. This is largely because of teachers' concept that if students have done something related with what they are going to listen in the class, they would pay less attention to the in-class listening activities. However, pre-listening activities are very important, especially for the C-level students. This is not only because these activities would help students build their confidence in listening, but also are positive in improving their listening comprehension. In the pre-listening activities, teachers shall provide students with context information for the specific listening task and try to activate students' prior knowledge. This would help build up their expectations for the coming information.

\section{STRATEGy: PRE-LiSTENing Vocabulary SuPPORT}

Researches on ESL listening have found that pre-listening support is crucial to the effective of students' listening comprehension. Previewing the test questions, repetition of the input, providing background knowledge about the topic, and vocabulary instruction are four types of the most used pre-listening supports. By comparing the effectiveness of the 
four types of pre-listening support, the research of Chang \& Read (2006) showed that the most effective type of support overall was providing information about the topic, followed by repetition of the input, and vocabulary instruction was the least useful form of support. However, other researches have demonstrated that there are strong correlations between vocabulary knowledge and listening comprehension (Bonk, 2000; Stahr, 2009). In Bonk's study, 59 Japanese learners of English as a foreign language (EFL) were examined to find the relationship between the students' level of familiarity with the lexis in the listening texts and their comprehension. It is found that participants knowing fewer than $75 \%$ of the content words in the input texts, including nouns, verbs, adjectives, and adverbs, were unable to have an acceptable comprehension score. Those knowing more than $90 \%$ all demonstrated good comprehension. In short, the study argues that 'acceptable comprehension levels were significantly associated with higher text-lexis familiarity' (Bonk, 2000). Similarly, in Stahr's study (2009) with 115 advanced Danish EFL learners, it was found that students with larger vocabulary would perform more effective in their listening comprehension. It is implied that the size of one's vocabulary plays a very important a role in listening comprehension.

Researches not only demonstrated the importance of vocabulary in listening comprehension, but also noted the value of lexical collocation instruction. In Hsu \& Hsu's study (2007), 34 English majors in two groups received three different types of instruction: single-item vocabulary instruction, lexical collocation instruction, and no instruction in each class, and right after the instruction they were requested to have a listening comprehension test. It is found that the participants who received lexical collocation instruction had the highest score in the test. Hsu \& Hsu's study clearly demonstrated the single-item vocabulary instruction is not effective compared with lexical collocation instruction. However, the focus of most studies on pre-listening vocabulary instruction was on single words. Although single words are certainly important, there are some shortages of instructions of such individual words. Firstly, such instructions would isolate individual words from the overall content of the passage, thus making learners difficult to comprehend the whole text. Secondly, such instructions do not help much the learners quickly and accurately parse the speech stream into meaningful chunks (Conklin \& Schmitt, 2008). In Pan et al.'s study (2018), multiword units are adopted to facilitate listening comprehension. By investigating the effectiveness of two different levels of 18-week vocabulary support, Pan et al. concluded that the expanded vocabulary support was particularly helpful for lower proficiency level students.

While Pan et al.'s study has provided some important evidence for the positive effect of the instruction of multiword units on listening; more studies are clearly needed to confirm this positive effect, considering especially the different situations in different regions. In addition, usually in a technology college, the English proficiency level is varied, and the situation in China is also different from that in Taiwan. Taken C-level students in Shanghai University as example, this paper would demonstrate how the pre-listening vocabulary support enhances the students' listening comprehension. As stated above, C-level students in Shanghai University are from different provinces with different English education background. Compared with other pre-listening support, these students are in great need of vocabulary support. And the expanded vocabulary support would be more effective to enhance their listening comprehension and confidence in listening. By comparing students with the expanded vocabulary support with those that received no expanded vocabulary support, this paper intends to demonstrate how vocabulary instruction before the listening task facilitate students' listening comprehension.

A total of 78 first-year students from two C-level classes participated in this research. They would have two 45minute classes on Monday and two on Wednesday. All the participants in the two classes had studied English for at least six years. They all have listening problems. During a ten-week semester, students from two classes were randomly assigned to either the experimental (EG) or control (CG) groups. Throughout the course of College English for C-level students, both EG and CG were assigned with same listening material and having same listening tests. The only difference lies in the pre-listening vocabulary support. EG would receive multiword units vocabulary support while CG not. These expanded vocabulary support activities were designed for students to have a better understanding not only of the vocabulary itself, but also of the whole lexical structure.

Test results drawn from eight listening quizzes, midterm and final exams as well as responses to lexical intervention questionnaires were collected. By analyzing the data collected, this research intended to answer the three research questions: (1) What were the effects of pre-listening vocabulary support on the final performance of the college students? (2) What types of listening behaviors did the treatment group exhibit? and (3) What were students' perceptions of prelistening lexical support in regard to their listening tasks? It is found that the EG lower-proficiency students benefited more from expanded listening support than their higher-proficiency counterparts did. In addition, from interview surveys it is found that students have a positive overall opinion of the role that listening support played. By motivating students to have control of their listening, this research would further facilitate students' independent listening study. In a word, pre-listening expanded vocabulary support can have strong and positive effect on ESL students with severe listening disabilities.

\section{ACKNOWLEDGMENTS}

The authors wish to thank Ph. D. Yin'er Zhu for her generous support of this project. This work was supported in part by a grant from Schools of Foreign Language, Shanghai University, namely "Strategies of Remedial Instructions for C-level Students in College English". 


\section{REFERENCES}

[1] Bonk, W. (2000). Second Language Lexical Knowledge and Listening Comprehension. International Journal of Listening, 14, $14-31$.

[2] Bossone, Richard M. (1966). "Remedial English Instruction in California Public Junior Colleges--An Analysis and Evaluation of Current Practices." https://files.eric.ed.gov/fulltext/ED012586.pdf (accessed 17/5/2018).

[3] Conklin, K., \& Schmitt, N. (2008). Formulaic Sequences: Are They Processed More Quickly than Nonformulaic Language by Native and Nonnative Speakers? Applied Linguistics, 29, 72-89.

[4] Chang, C.S., \& Read, J. (2006). The Effects of Listening Support on the Listening Performance of EFL Learners. TESOL Quarterly, 40, 375-397.

[5] Feyten, C.M. (1991). The power of listening ability: An overlooked dimension in language acquisition. The Modern Language Journal, 75, 173-180.

[6] Habte-Gabr, E. (2006). The Importance of Socio-affective Strategies in Using EFL for Teaching Mainstream Subjects. The Journal of Humanizing Language Teaching, 8(5). http://www.hltmag.co.uk/sep06/sart02.htm\#C1 (accessed 17/5/2018).

[7] Ho, Jia-Yiing (2016). "English Remedial Instruction to Enhance Low-Achieving Students' Vocabulary." Issues in Language Studies, 5(1): 64-83.

[8] Hsu, J.Y., \& Hsu, L.C. (2007). Teaching Lexical Collocations to Enhance Listening Comprehension of English Majors in a Technological University of Taiwan. Soochow University Journal of Foreign Languages and Cultures, 24, 1-34.

[9] King, Arthur H. (1973) "Notes on Remedial English at Higher--Educational Level." English Language Teaching 27.3: 245-50.

[10] Mendelsohn, D.J. (1995). Applying Learning Strategies in the Second/Foreign Language Listening Comprehension Le sson. In, A Guide for the Teaching of Second Language Listening. Eds. D. J. Mendelsohn, \& J. Rubin. San Diego, CA: Dominie Press: $132-150$.

[11] Mendelsohn, D. (1998). Teaching Listening. Annual Review of Applied Linguistics, 18, 81-101.

[12] Nunan, D. (1998). Approaches to Teaching Listening in the Language Classroom. Paper presented at the Korea TESOL Conference, Seoul.

[13] Oxford, R. L. (1990). Language Learning Strategies: What Every Teacher Should Know. Boston: Heinle \& Heinle.

[14] O`Malley, J .M. \& Chamot, A. U. (2001). Learning Strategies in Second Language Acquisition. Shanghai: Shanghai Foreign Language Education Press.

[15] Pan, Yi-Chun, Tsai, Tzung-Hung, Huang,Yueh-Kuey \& Liu, Dilin. (2018). Effects Of Expanded Vocabulary Support On L2 Listening Comprehension. Language Teaching Research, 22(2), 189-207.

[16] Qiong, Jiang. (2012). A Research on the Methods of e- learning Remedial Instruction Establishment. Journal of Lishui University, 117-120.

[17] Rost, M. (2002). Teaching and Researching Listening. London: Longman.

[18] Stahr, L.S. (2009). Vocabulary Knowledge and Advanced Listening Comprehension in English as a Foreign Language. Studies in Second Language Acquisition, 31, 577-607.

[19] Torgesen, J. K., Alexander, A. W., Wagner, R. K., Rashotte, C. A., \& al, e. (2001). Intensive Remedial Instruction for Children with Severe Reading Disabilities: Immediate and Long-Term Outcomes from Two Instructional Approaches. Journal of Learning Disabilities, 34(1), 33-58.

[20] Vandergrift, L. (2003). Listening: theory and practice in modern foreign language competence. http://www.llas.ac.uk/resources/gpg/67 (accessed 17/5/2018).

Xiuli Zhang, Ph. D., teaches college English and English literature at Shanghai University. Her interests include literary theory and second language acquisition. 